\title{
CHARACTERISTICS OF PROBIOTIC KOUMISS FROM GOAT MILK WITH ADDITION OF ROSELLE EXTRACT (Hibiscus Sabdariffa Linn)
}

\author{
E. Nuraeni, I.I. Arief and M. S. Soenarno \\ Department of Animal Production and Technology, Faculty of Animal Science, \\ Bogor Agricultural University, \\ Jl. Agatis, Darmaga Campus, Bogor 16680 - Indonesia \\ Corresponding E-mail : irma_isnafia@yahoo.com
}

Received April 08, 2014; Accepted May 26, 2014

\begin{abstract}
ABSTRAK
Susu kambing dan rosella (Hibiscus sabdariffa Linn) dikenal masyarakat sebagai bahan makanan yang memiliki sifat fungsional untuk kesehatan. Penelitian ini menggunakan Lactobacillus acidophilus RRAM-01 dan Lactococcus lactis RRAM-01 sebagai bakteri probiotik, dan Saccharomyces cereviceae. Tujuan penelitian ini adalah mempelajari karakteristik koumiss (produk fermentasi) probiotik susu kambing dengan penambahan ekstrak rosella. Hasil analisis menunjukkan bahwa penambahan ekstrak rosella yang berbeda $(0 \%, 0,5 \%$, dan $1 \%)$ pada koumiss probiotik susu kambing tidak mempengaruhi karakteristik kimia maupun mikrobiologi koumiss. Pengolahan susu kambing menjadi koumiss dapat menekan pertumbuhan koliform dan memiliki aktivitas penghambatan yang kuat terhadap Escherichia coli ATCC 25922 melalui uji difusi sumur. Analisis mikrobologi menggunakan metode agar tuang. Populasi bakteri asam laktat menunjukkan bahwa koumiss telah memenuhi standar produk probiotik $\left(10^{11} \mathrm{cfu} / \mathrm{mL}\right)$, koliform tidak terdeteksi, sehingga sesuai dengan kriteria Badan Pengawasan Obat dan Makanan (BPOM) sebagai pangan fungsional probiotik. Berdasarkan uji mutu hedonik penambahan ekstrak rosella meningkatkan intensitas warna merah dan kekentalan koumiss, namun tidak berpengaruh terhadap aroma tape dan rasa asam koumiss.
\end{abstract}

Kata kunci : koumiss, probiotik, rosella (Hibiscus sabdariffa L), susu kambing

\begin{abstract}
Goat milk and roselle (Hibiscus sabdariffa Linn) are food ingredients with health functional properties. This research used Lactobacillus acidophilus RRAM-01 and Lactococcus lactis RRAM-01 which had been proven as probiotic, and Saccharomyces cereviceae. Saccharomyces cereviseae was used to produce specific flavor components in koumiss (bacterial fermentation product). The objective of this research was to study the characteristics of goat milk probiotic koumiss added that with roselle extract. The results showed that the addition of different concentration of roselle extract $(0 \%, 0.5 \%$, and $1 \%$ ) in the goat milk probiotic koumiss had no effect on chemical and microbiological characteristics of koumiss. Goat milk processed into koumiss had ability to suppress the growth of coliform and had strong inhibition activity against Escherichia coli ATCC 25922 as tested by agar diffusion test. Microbiological analysis used in this research was the pour plate method. Population of lactic acid bacteria indicated that the product fulfilled standards as probiotics koumiss $\left(10^{11} \mathrm{cfu} / \mathrm{mL}\right)$, coliform was not detected in the products, therefore the products met the criteria of The National Agency of Drug and Food Control (NA-DFC) as probiotic functional food. Sensory evaluation was conducted by using hedonic quality test. Based on the hedonic quality test, addition of different concentrations of roselle extract increased the intensity of red color and koumiss viscosity, but had no effect to the aroma and sourness of koumiss.
\end{abstract}

Keywords : goat milk, koumiss, probiotic, roselle (Hibiscus sabdariffa Linn) 


\section{INTRODUCTION}

Koumis is a bacterial fermentation product, derived from middle Asia and usually made from horse's milk fementation with lactic acid and yeast (Seydim et al., 2010). Common bacteria used as culture starter was lactic acid bacteria that made antimicrobial substrates (lactic acid, bacteriosin, alcohol and $\mathrm{H}_{2} \mathrm{O}_{2}$ ) and has antagonistic characteristic with pathogen bacteria. In Rusia, koumis had been used as medicine for TBC caused by Mycobacterium tuberculosis (Tamime, 2006).

Koumis is traditional beverage that has well known yet to people in the world and the production is still in limited geography (Malacarne et al., 2002). It is caused by the limited supply of horse milk production. The solution is to produce koumiss from other animal milk like goat milk.

Horse milk production in Indonesia is limited in supply and certain area also the production is still low. Dairy goat is considered a second rank in milk production after cow's milk. Korhonen and Anna (2006) reported that goat milk protein contain bioactive component such as angiotensin conventing enzyme (ACE), inhibitory peptides and peptide hypertensive. The component has effect to give immunity for nonimmune disease and to control microorganism infection (Hayes et al., 2007). According to the last research, goat milk fermentation can decrease Mycobacterium tuberculosis growth because it had the function as natural antiseptic in human body; this property is similar to horse milk fermentation (Pana, 2004).

Red roselle (Hibiscus Sabdariffa L) is a plant with many functions for our health. Roselle contains some nutrition as non hypertension, antioxidant and high content of vitamin $\mathrm{C}$ helps digestion process. Roselle has been used at agent therapy in treating cancer, treating hypertension and its lipid-lowering. In addition, roselle can also improve sensory value of the product (Kustyawati and Ramli, 2008). The research about characteristics of goat milk probiotic koumiss added with roselle extract is one way process to know the characteristics of goat milk as raw material to replace horse milk in koumiss production and the effect of roselle to the characteristic of koumiss product. The functional properties of roselle for health is usefull to improve functional characteristic of fermented milk for human's health therapy. The purposes of this research were to evaluate the chemical and microbiology characteristics, antimicrobial activity, and sensory quality of koumiss probiotic goat milk with different treatments of roselle extract (Hibiscus Sabdariffa L).

\section{MATERIALS AND METHODS}

\section{Roselle Extraction}

Dry roselle flower was prepared and smoothed in blender. Twenty gram of roselle powder was put in Erlenmeyer and mixed with $100 \mathrm{~mL}$ aquadest. The solvent of roselle was heated in waterbath at temperature of $60^{\circ} \mathrm{C}$ for 30 min (Hermawan et al.., 2010).

\section{Koumiss Production}

Goat milk was produced from Faculty of Animal Science's farm. One liter of goat milk was pasteurized at $65^{\circ} \mathrm{C}$ for $30 \mathrm{~min}$, then cooled to a temperature of $28^{\circ} \mathrm{C}$. Koumiss starter culture was divided into three equal parts, each part of milk was inoculated with Lc. lactis, Lb. acidophilus and then incubated at $37^{\circ} \mathrm{C}$ for $7 \mathrm{~h}$ and $S c$. cereviceae at $25^{\circ} \mathrm{C}$ for $5 \mathrm{~h}$, respectively. Next, it was mixed Lc. lactis, Lb. acidophilus and Sc. cereviceae as much as $3-5 \%(\mathrm{v} / \mathrm{v})$ into the goat pasteurized milk. The mixture of milk and starter cultures were incubated at $28^{\circ} \mathrm{C}$ for $24 \mathrm{~h}$ to form the desired starter (modified method of Rahman et al., 1992). To produce koumiss, one liter of goat milk was pasteurized at $65^{\circ} \mathrm{C}$ for $30 \mathrm{~min}$, then inoculated with a starter (5\%) after temperature reached $28^{\circ} \mathrm{C}$. Then, it was incubated at $25^{\circ} \mathrm{C}$ for $18 \mathrm{~h}$ (modified method of Astawan et al., 2012) (Figure1).

\section{Chemical characteristics Analysis}

The chemical composition of a processed product was the criteria for assessment the quality of the product. Koumiss characteristic was analyzed by using AOAC method (1995) consisted of $\mathrm{pH}$, total acidity (TA), water, ash, protein, crude fiber, and fat contents.

\section{Microbiology Characteristics Analysis}

The method used in koumiss microbiology enumeration was pour plate method (Fardiaz, 1992). Colony microbe was enumerated based on Plate Count Standard (PCS) based on BAM (2011).

\section{Antimicrobial activity by Agar Diffusion Test}

The inhibition test to E. coli bacteria used 


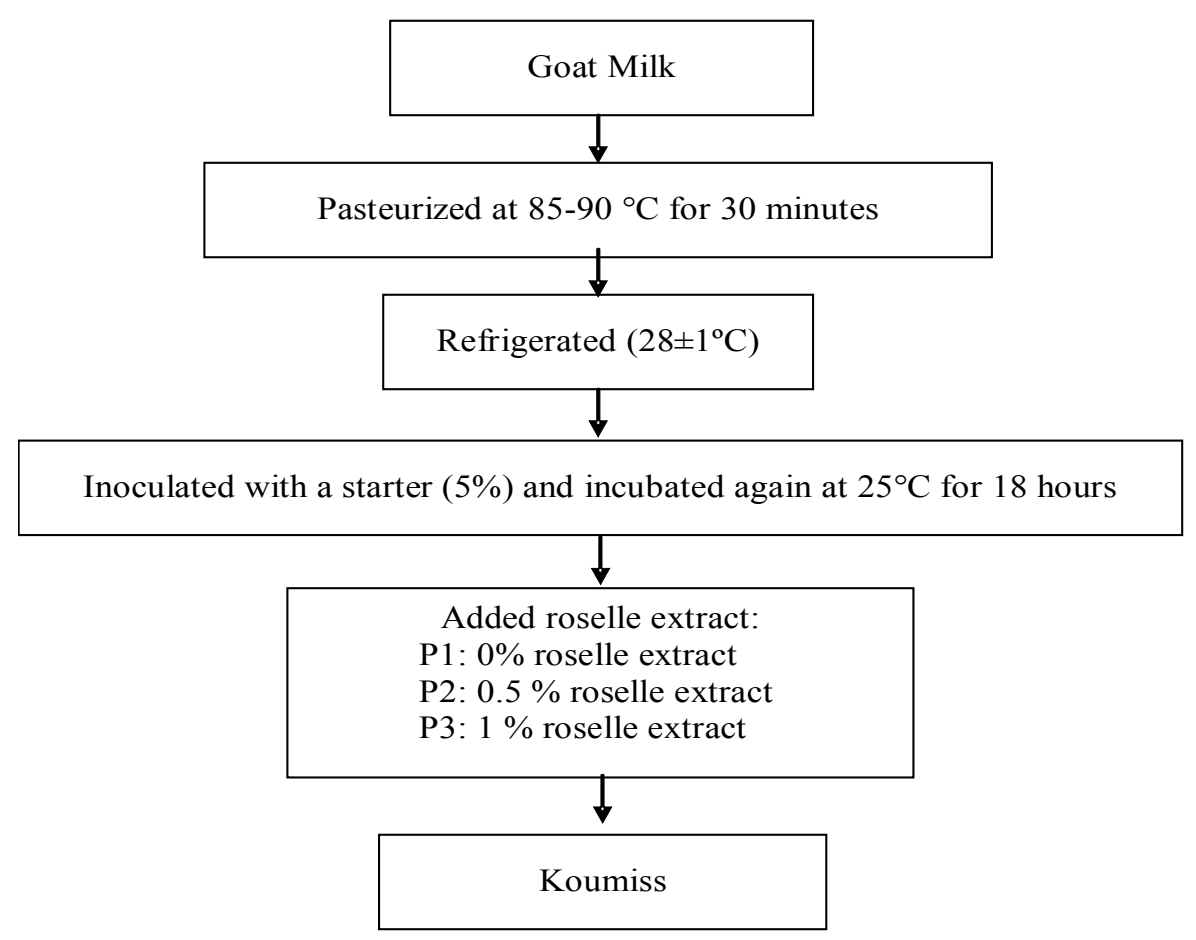

Figure 1. The Process of Producing Koumiss Product

agar diffusion test (Arief et al., 2012).

\section{The Test of Sensory Characterictic}

The sensory characteristic test used was the hedonic quality test. The test consisted of color, aroma, viscosity, and sourness. Panelists used were trained panelist about 30 people. Three samples of koumiss with different roselle extract concentration had already marked with specific code were given to panelists. The scale of value that used in the test was $1,2,3$, and 4 .

\section{Statistical Analysis}

The experimental design used in this study was a completely randomized design (CRD). Treatment being tested was the different percentage addition of roselle extract $(0 \%, 0.5 \%$, and $1 \%$ ). Each treatment was repeated for three replication and duplo for each replicate. Parametric data were analyzed using analysis of variance (ANOVA) and data were analyzed using the nonparametric kruskal-wallis at the $95 \%$ significance level using software statistix 8 . Tukey test used for significantly difference $(\mathrm{P}<0.05)$ tukey test (Steel and Torrie, 1980). Mathematical model used was according to Matjik and Sumertajaya (2000) as follows: $\mathrm{Y}_{\mathrm{ij}}=\mu+\alpha_{\mathrm{i}}+\varepsilon_{\mathrm{ij}}$
Where:

$Y_{\mathrm{ij}}$ : The response obtained from standard treatment and replicates $i$-th to $j$-th

$\mu \quad$ : Average value

ai : Effect of treatment to level-i

$\varepsilon_{\mathrm{ij}} \quad$ : Error

\section{RESULTS AND DISCUSSION}

\section{Morphological Examination and Total Bacteria Colonies}

Koumiss starter culture examination was aimed to study the characteristics of the cell wall (Gram staining), morphology (form and structure) and to determine the total population from each bacteria. Microbial strains used in this study consisted of Lactococcus lactis bacteria RRAM01, Lactobacillus acidophilus RRAM-01 and yeast Saccharomyces cereviceae. Test results and characteristics of the total population of each bacteria is presented in Table 1 .

Lactic acid bacteria population had met the minimum number required in the manufacture of fermented milk that was equal to $10^{8} \mathrm{cfu} / \mathrm{mL}$ (Salminen and Wright, 1998). Calculation of population of each type of bacteria, was performed on the starter koumiss and the result 
Table 1. Characteristics and Total Microbial Population

\begin{tabular}{lccl}
\hline \multicolumn{1}{c}{ Bacteria } & $\begin{array}{c}\text { Population } \\
(\mathrm{cfu} / \mathrm{mL})\end{array}$ & Gram stain & \multicolumn{1}{c}{ Morphological } \\
\hline Lactococcus lactis & $1.06 \times 10^{10}$ & Gram-positive & Globular, short or long chain. \\
Lactobacillus acidophilus & $6.40 \times 10^{11}$ & Gram-positive & $\begin{array}{l}\text { Rod-shaped, short-chain chains. } \\
\text { Saccharomyces cereviceae }\end{array}$ \\
\hline
\end{tabular}

was population of total $\mathrm{LAB}$ and yeasts were 2.80 x $10^{12} \mathrm{cfu} / \mathrm{mL}$ and $5.20 \times 10^{11} \mathrm{cfu} / \mathrm{mL}$, respectively.

Test results showed that the starter culture koumiss demonstrated suitability to the morphological characteristics of each bacteria and yeast. Bacterium Lactococcus lactis and Lactobacillus acidophilus was belongs to the group of Gram-positive lactic acid bacteria, according to Chandan et al. (2008)

\section{Chemical Characteristics of Koumiss}

The nutritional quality of fresh goat milk was met to SNI (2009). Water content of fresh goat milk was $84.25 \% \mathrm{wb}$, ash content was 0.78 $\% w b$, peotein content was $3.24 \% w b$ and fat content was $6.54 \%$ wb. Coliform was below of SNI (2009).

Koumiss is a type of fermented milk generally made from fermented horse milk using lactic acid bacteria and yeasts. Lactic acid bacteria (LAB) plays important role in producing lactic acid and yeast which is responsible for producing ethanol and carbon dioxide (Surono, 2004). Koumiss has similarity with kefir, because koumiss also produces lactic acid and alcohol as well as kefir. The difference lies in the structure of starter cultures used in the manufacture of both types of milk fermentation, where the starter koumiss is not granular (Wang et al., 2008). Based on the $\mathrm{pH}$ value, koumiss is grouped into three types: strong koumiss ( $\mathrm{pH} 3.3-3.9)$, medium (pH 3.9-4.5), and mild ( $\mathrm{pH} 4.5-5)$ (Danova et al., 2005). The research used application of goat's milk as a raw material for making probiotic koumiss and the addtion of roselle flower extract (Hibicuss sabdarifa L) as the treatment. Goat milk is milk from a healthy mother goat udder and obtained with the good way (BSN, 1992). Goat milk composition per $100 \mathrm{~g}$ that used in this research was $87.34 \%$ moisture, $0.8 \%$ ash, $5.22 \%$ fat, $3.9 \%$ protein, and $0.19 \%$ crude fiber based on wet weight.

Chemical analysis include total $\mathrm{pH}$, total acidity (TA), moisture content, ash content, protein content, fat content, and crude fiber content. The results presented in Table 2. The main results of the metabolism of lactic acid bacteria fermentation were the lactic acid that reduced $\mathrm{pH}$ of the final product. The decrease in $\mathrm{pH}$ and increase in TA was occurred due to accumulation of organic acid metabolism. Koumiss $\mathrm{pH}$ values ranged from 3.6 to 3.8. Based on the $\mathrm{pH}$ value, the resulting koumiss was included in the group of strong koumiss $(\mathrm{pH} 3.3-$ 3.9) (Danova et al., 2005). Low $\mathrm{pH}$ value was due to the production of organic acids by Lactococcus lactis and Lactobacillus achidopillus. Total acidity value of koumiss with different treatments fulfilled Indonesian standards for flavour fermented milk which were $0.5-2 \%$ (BSN, 2009). The addition of roselle extract had no significant different $(\mathrm{P}>0.05)$ on $\mathrm{pH}$ value and TA.

Addition of roselle extract had no significant effect to the moisture, ash, protein, fat and crude fiber content. This was caused by addition of small percentage of extract $(0 \%, 0.5 \%$, and $1 \%)$. Levels of protein and fat in goat milk koumiss were higher than horse milk koumiss. Koumiss mare's milk has a protein content of $21 \%$ and a fat content of 12\% (Seydim, 2010). This was caused by differences in the nutritional composition of mare's milk with goat milk (per 100 g). Protein and fat content of goat milk is higher than horse milk (Chandan et al., 2008).

\section{Microbiological Characteristics Koumiss}

Microbiological characteristics observed were total lactic acid bacteria (LAB), total yeast and total coliform (Table 3). Koumiss microbiological characteristics of goat's milk with 
Table 2. Chemical Characteristics of Koumiss Probiotic Goat Milk

\begin{tabular}{lccc}
\hline \multirow{2}{*}{ Variable } & \multicolumn{3}{c}{ Koumiss with roselle extract } \\
\cline { 2 - 4 } & $0 \%$ & $0.5 \%$ & $1 \%$ \\
\hline $\mathrm{pH}$ & $3.72 \pm 0.06$ & $3.78 \pm 0.01$ & $3.76 \pm 0.06$ \\
Total Acidity (TA) & $1.52 \pm 0.05$ & $1.56 \pm 0.05$ & $1.58 \pm 0.04$ \\
Water $(\% \mathrm{wb})$ & $85.72 \pm 0.14$ & $85.82 \pm 0.39$ & $85.67 \pm 0.32$ \\
Ash $(\% \mathrm{wb})$ & $0.78 \pm 0.056$ & $0.76 \pm 0.046$ & $0.78 \pm 0.040$ \\
Protein $(\% \mathrm{wb})$ & $4.04 \pm 0.171$ & $4.09 \pm 0.387$ & $3.91 \pm 0.257$ \\
Fat $(\% \mathrm{wb})$ & $6.56 \pm 0.137$ & $6.38 \pm 0.533$ & $6.60 \pm 0.457$ \\
Crude fiber $(\% \mathrm{wb})$ & $0.11 \pm 0.038$ & $0.16 \pm 0.053$ & $0.30 \pm 0.164$ \\
\hline
\end{tabular}

Table 3. Microbiological Characteristics of Goat Milk Probiotic

\begin{tabular}{|c|c|c|c|}
\hline \multirow{2}{*}{ Variable } & \multicolumn{3}{|c|}{ Koumiss with increasing roselle extract $\left(\log _{10} \mathrm{cfu} / \mathrm{mL}\right)$} \\
\hline & $0 \%$ & $0.5 \%$ & $1 \%$ \\
\hline $\mathrm{LAB}$ & $11.42 \pm 0.73$ & $12.49 \pm 1.33$ & $13.61 \pm 0.31$ \\
\hline Khamir & $11.37 \pm 1.39$ & $12.55 \pm 0.37$ & $12.88 \pm 0.51$ \\
\hline Coliform & 0 & 0 & 0 \\
\hline
\end{tabular}

the addition of probiotic and roselle extract had no significant different $(\mathrm{P}>0.05)$ in relation with the amount of LAB, yeasts, and, coliforms. Lactic acid bacteria used in this study was Lactococcus lactis and Lactobacillus achidopillus. Each LAB had a high population so that the total population of the final product was relatively high. This result was accomplied with yoghurt probiotic added Lactobacillus achidopillus could increase population of lactic acid bacteria of the product (Astawan et al., 2012). Lactobacillus achidopillus RRAM-01 and Lactococcus lactis RRAM-01 was a probiotic bacterium. Lactobacillus acidophillus have been proven as probiotic because it has benebicial fuction such as it could give antimicrobial activities againts pathogenic bacteria (Arief et al., 2010), and could prevent hematology health status of rat (Astawan et al., 2011) According to the result, LAB populations had met with international standards for koumiss probiotic drink that was a minimum of $10^{7}$ $\mathrm{cfu} / \mathrm{mL}$ (Davidson et al., 2000). Probiotics are non pathogenic microbes which when it ingested, produced a positive impact on the health and physiology of the host (Commane et al., 2005). Probiotic bacteria can affect the physiology directly or indirectly by stimulating the immune system (Dewater, 2003). Total populations of $\mathrm{LAB}$ and yeasts koumiss were higher than the total population of the initial starters. These were due to the synergistic relationship between the yeast (Saccharomyces cereviceae) with LAB (Lactococcus lactis and Lactobacillus achidopillus). Lactic acid bacteria had the ability to break down complex component into simpler components, one of which was lactose. Lactose in milk was broken down into simple sugar monomer called glucose and galactose. The sugars could be utilized by yeast as a source of energy, because the yeasts prefer simple sugars rather than complex components, for its growth (Seydim et al., 2010).

In addition, fermentation by Lactococcus lactis and Lactobacillus achidopillus produced 
lactic acid, thereby creating acidic conditions (lower $\mathrm{pH}$ ) in the fermentation medium. This condition was useful for Saccharomyces cereviceae, because Saccharomyces cereviceae prefered acidic conditions than alkaline conditions (Bennett et al., 1999). The existence of Saccharomyces cereviceae was profitable for Lactococcus lactis and Lactobacillus achidopillus due to metabolites produced by Saccharomyces cereviceae, namely organic compounds (ethanol) and carbon dioxide. Carbon dioxide balanced oxygen level in the medium and ethanol was able to break down toxic $\mathrm{H}_{2} \mathrm{O}_{2}$ into non-toxic compounds with the aid of peroxidase. Therefore, the yeast will produce $\mathrm{CO}_{2}$ which can balance the levels of oxygen in the medium. The statement was supported by Gilliland (1986) which states that excessive oxygen in the growth of bacteria can cause a decrease in cell viability, due to excess oxygen to form hydrogen peroxide which are toxic to cells.

Microorganisms often used as an indicator of sanitation in food were coliform bacteria. Coliform in fresh goat milk was about $2.5 \times 10^{2}$ $\mathrm{cfu} / \mathrm{mL}$, while coliform in koumiss was not present at all treatments due to the possibility that colliform would not survive at a low $\mathrm{pH}$. Coliform decrease in koumiss was caused by acid production from LAB and roselle extract. Acid would decrease $\mathrm{pH}$ to below $\mathrm{pH}$ range of bacteria growth and these acids were in the form of not dissolated and could rapidly diffuse into the microbial cell, causing the cell to be damaged. Furthermore acids dissolated would break down into anions and protons, where the proton $\left(\mathrm{H}^{+}\right)$ will be entered into the cell that causes the metabolic function is compromised, such as the acidification of the cytoplasm, inhibition transfer substrate, synthesis of macromolecules and overall growth bacteria is inhibited (Dewater, 2003).

Inhibitory activity against Escherichia coli by roselle extract and antimicrobial koumiss was seen by observing inhibition zone against pathogenic bacteria $E$. coli with the well diffusion agar method. The amount of inhibition zones was shown in Table 4.

Wide minimum inhibitory zone was one $\mathrm{mm}$, one positive $(+)$ when the clear area between 2-5 $\mathrm{mm}$ and strong inhibitory activity $(++)$ when more than five mm (Jacobsen, 1999). Based on the inhibition zone diameter, koumiss had strong inhibitory activity against E.coli. Lactobacillus acidophillus could inhibit pathogenic bacteria
Table 4. Inhibition Zone of Koumiss and Roselle Extract against $E$. coli

\begin{tabular}{lc}
\hline Sample & $\begin{array}{c}\text { Inhibition Zone } \\
(\mathrm{mm})\end{array}$ \\
\hline Roselle extract & $19.37 \pm 2.03$ \\
Koumiss & $8.46 \pm 1.10$ \\
Koumiss 0.5 \% Roselle extract & $9.48 \pm 1.95$ \\
Koumiss 1\% Roselle extract & $8.08 \pm 0.77$ \\
\hline
\end{tabular}

with strong activities such enteropathogenic E. coli by in vivo analysis (Arief et al., 2010).

Roselle and koumiss extract could inhibit pathogenic bacteria E.coli in a population of $10^{6}$ cfu/mL, this also supported by Rostinawati (2009) which showed that the roselle flower had antibacterial activity. Inhibition zone formed on roselle extract was greater than the inhibition zone formed by koumiss which reached zone diameter of $19.37 \pm 2.03 \mathrm{~mm}$. This was due to high concentration of flavonoids and organic acids that occured in roselle extract like inhibiscus acid, ascorbic acid, malic acid and protokatekin acids (Arelano et al., 2004). Inhibition occured because the content of antimicrobials in koumiss were in the form of organic acids, bacteriocins and alcohol (Surono, 2004).

\section{Organoleptic Characteristics of Koumiss}

Organoleptic test performed in this study was hedonic quality test. The parameters used were color, aroma alcoholic aroma, consistency and flavor. Koumiss organoleptic test results is presented in Table 5.

Hedonic quality test results showed that the addition of roselle extract treatment was significant $(\mathrm{P}<0.05)$ on the color of koumiss. Koumiss with the addition of roselle extract was intended from white to pink. The color difference was caused by the differences concentration in the addition of roselle extract. The red color on koumiss was formed due to the red pigment in the roselle anthocyanin (Astawan and Andreas, 2008).

Hedonic quality test results showed that the addition of Roselle extract treatment had no significant effect $(\mathrm{P}>0.05)$ to the koumiss aroma. Aroma on koumiss was included into weak aroma. Aroma was due to a number of volatile components derived from the products that can be detected by the sense of smell (Rachmawati, 
Table 5. Organoleptic Characteristics of Probiotic Goat Milk Koumiss

\begin{tabular}{lccc}
\hline \multirow{2}{*}{ Variable } & \multicolumn{3}{c}{ Koumiss with addition roselle extract } \\
& $0 \%$ & $0.5 \%$ & $1 \%$ \\
\hline Colour & $1.00 \pm 0.00^{\mathrm{a}}$ & $1.50 \pm 0.51^{\mathrm{b}}$ & $1.93 \pm 0.52^{\mathrm{c}}$ \\
Tapay aroma & $2.17 \pm 0.75$ & $1.97 \pm 0.72$ & $2.10 \pm 0.76$ \\
Viscosity & $2.17 \pm 0.65^{\mathrm{a}}$ & $2.00 \pm 1.02^{\mathrm{ab}}$ & $2.63 \pm 0.81^{\mathrm{b}}$ \\
Sour taste & $2.40 \pm 0.77$ & $2.37 \pm 0.76$ & $2.77 \pm 0.77$ \\
\hline
\end{tabular}

Color: $1=$ white; $2=$ pink; $3=$ red; $4=$ very red. Tapay aroma: $1=$ very weak; $2=$ weak; $3=$ strong; $4=$ very strong. Viscosity: $1=$ very dilute; $2=$ rather thick; $3=$ thick; $4=$ highly viscous. Sour taste: $1=$ not sour; 2 = slightly acid; 3 = acid; 4 = highly acidic.

Different small superscript in the same row indicate significantly different results $(\mathrm{P}<0.05)$.

2001). Koumiss aroma associated with total acid and alcohol content. Ester component koumiss aroma was affected by the reshuffle resulting from alcohol. Ester produced from the reaction between organic acids with alcohols (Hesseltine, 1979).

Hedonic quality test results showed that the addition of Roselle extract treatment had significant $(\mathrm{P}<0.05)$ effect on the viscosity koumiss which was not added roselle extracts and with added $1 \%$ koumiss roselle extract. Differences in viscosity at koumiss was influenced by the addition of acid formation due to differences in roselle extract, which caused protein denaturation process at the isoelectric $\mathrm{pH}$ so that proteins precipitated to form a gel (Sodini et al., 2002).

Hedonic quality test results showed that the addition of Roselle extract treatment had no significant effect $(\mathrm{P}>0.05)$ to the sour taste in koumiss. These results were consistent with the results of testing the acidity $(\mathrm{pH})$ koumiss which also showed that the addition of roselle treatment had no significant effect to the acidity.

\section{CONCLUSION}

The addition of roselle extract different had no affect to the chemical and microbiological characteristics goat milk koumiss probiotic. Koumiss goat milk could suppress the growth of coliform and had a strong inhibitory activity against E. coli. Population koumiss lactic acid bacteria in probiotic products had met the standards $\left(10^{7} \mathrm{cfu} / \mathrm{mL}\right)$. Based on the $\mathrm{pH}$ value, the resulting koumiss was strong koumiss group.
Hedonic quality tests showed that the addition of roselle extract was capable in increasing red color and viscosity of koumiss.

\section{REFERENCES}

AOAC (Association of Official Analytical Chemistry). 1995. Official Methods of Analysis. Association of Official Analytical Chemistry.

BAM (Bacteriological Analytical Manual). 2011. Aerobic Plate Count. [Internet]. Bogor (ID): Dramaga. $\quad[10$ October 2012]. http:/cfsan.fdagov/abam/bam.html.

BSN (Badan Standardisasi Nasional). 2009. SNI. 01-7552-2009: Susu Fermentasi berperisa. Jakarta(ID): Badan Standardisasi Nasional.

BSN (Badan Standarisasi Nasional). 1992. SNI. 01-3141-1992: Susu kambing. Jakarta (ID): Badan Standardisasi Nasional.

Arelano, H.A., S.F. Romero and M.A.C.J. Tortoriello. 2004. Effectivencess and tolerability of a standardizided extract from hibiscus sabdariffa in patients with mild to moderate hypertention: a controlled and randomized clinical trial. Phytomedicine 11:375-382.

Arief, I.I., B.S.L. Jenie, M. Astawan and A.B. Witarto. 2010. The effectiveness of probiotic Lactobacillus plantarum 2C12 and Lactobacillus acidophilus 2B4 as antidiarrhea on rat. Med. Pet. 43:137-143

Arief, I.I., B.S.L. Jenie, T. Suryati, G. Ayuningtias and A. Fuziawan. 2012. Antimicrobial activity of bacteriocin from indigenous 
Lactobacillus plantarum $2 \mathrm{C} 12$ and its application on beef meatball as biopreservative J. Indonesian Trop. Anim. Agric. 37:90-96.

Astawan, M. and L.K. Andreas. 2008. Khasiat Warna-Warni Makanan. Gramedia. Jakarta.

Astawan, M., T. Wresdiyati, I.I. Arief and E. Suhesti. 2011. Hematology profile of Rattus norvegicus infected by enteropathogenic Escheria coli and fed probiotics. Med. Pet. 34(1):7-13.

Astawan, M., T. Wresdiyati, Suliantri, I.I. Arief and R. Septiawan. 2012. Production of synbiotic yogurt-like using indigenous lactic acid bacteria as functional food. Med. Pet. 35(1):9-14.

Bennett, A., R.I. Rowe, N. Soch and C.D. Eckhert. 1999. Boron Stimulates Yeast (Saccharomyces cereviceae) Growth. University of California. Los Angeles.

Chandan, R.C., A.K. Nagendra and P. Shah P. 2008. Dairy Processing and Qual Assurance. Wiley-Blackwell. USA.

Commane D, R Hughes, C Shortt and I Rowland. 2005. The potential mechanisms involved in the anticarcinogenicaction of probiotics. Mutation Research. 591:276-289.

Danova, S., K. Petrov, P. Pavlov and P. Petrova. 2005. Isolation and characterization of Lactobacillus strains involved in koumiss fermentation. Int. J. Dairy Technol. 58(2):100-105.

Davidson, R.H., S.E. Duncan, C.R. Hackney, W.N. Eigel and J.W. Boling. 2000. Probiotic culture survival and implications in fermented frozen yoghurt characteristics. J. Dairy Sci. 83:666-673.

Dewater, J.V. 2003. Yogurt and immunity: the health benefits of fermented milk products that contain lactic acid bacteria. In: Handbook of Fermented Functional Foods. (E.R. Farnworth, ed). CRC Pr. London.

Fardiaz, S. 1992. Mikrobiologi Pangan I. Gramedia Pustaka Utama. Jakarta.

Gilliland, S.E. 1986. The lactobacilli: milk product. In: Bacterial Starter Cultures for Foods. (S.E. Gililland, ed). CRC Pr. Florida.

Hayes, M, C. Stanton, H. Slattery, D. O'sullivan and C. Hill. 2007. Casein fermentate of Lactobacillus animalis dpc6134 contains a range of novel propeptida angiotensinconverting enzyme inhibitors. Appl Environ Microbiol. 73:4658-4667.

Hermawan, R., E.K. Hayati, U.S. Budi and A.
Barizi. 2010. Effect of temperature, $\mathrm{pH}$ on total concentration and color stability of anthocyanins compound extract roselle calyx (Hibiscus sabdariffa L). Alchemy. 2(1):104-157.

Hesseltine, C.W. 1979. Microorganisme involves in food fermentation in tropical asia. Proceedings, International Symposium on Mic Aspects of Food Storage Process and Fermentation in Tropical Asia, Food Technol and Develop Centre, Bogor, Indonesia, December 10-13, 1979.

Jacobsen, C.N. 1999. Screening of probiotic activities of fourty-seven strain of Lactobacillus spp. by in vitro techniques and evaluation of the colonization ability of five selected strains in human. J. Appl. Environ Microbiol. 65(11):4949-4956.

Korhonen, H. and P. Anna. 2006. Bioactive peptides: production and functionality. J. Dairy Sci. 6:945-960.

Kustyawati, M.E. and S. Ramli. 2008. Pemanfaatan hasil tanaman hias Roselle sebagai bahan minuman. Seminar Nasional Sains dan Teknologi II. Universitas Lampung, Lampung, Indonesia, 2008.

Malacarne, M., M. Francesca and S. Andrea. 2002. Protein and fat composition of mare's milk: some nutritional remarks with reference to human and cow's milk. Int. Dairy J. 12(1):869-871.

Pana, Z.K. 2004. Perbandingan Pengaruh Susu Kambing dan Susu Kuda Sumbawa terhadap Pertumbuhan Mycobacterium tuberculosis secara In vitro. Master Thesis. Institut Pertanian Bogor, Bogor.

Putri, W.D.R., T.D. Widyaningsih and D.W. Ningtyas. 2008. Dried mixed culture of Lactobacillus sp and Saccharomyces cereviceae production. J. Teknol. Indust. Pert. 9(2):38-149.

Rachmawati, N. 2001. Pengaruh Penambahan Tape dan Tepung Tape Ubi Kayu (Manihot esculenta crantz) terhadap Mutu Organoleptik dan Umur Simpan Cake Tape sebagai Salah Satu untuk Memanfaatkan dan Meningkatkan Nilai Produk Tradisional. Bachelor Thesis. Institut Pertanian Bogor, Bogor.

Rahman, A., F. Srikandi, W.P. Rahayu, Suliantari and C.C. Nurwitri. 1992. Bahan Pengajaran: Teknologi Fermentasi Susu. Pusat Antar Universitas Pangan dan Gizi, Institut Pertanian Bogor, Bogor. 
Rostinawati, T. 2009. Aktivitas Antibakteri Ekstrak Etanol Bunga Roselle (Hibiscus sabdariffa L) terhadap Escherichia coli, Salmonella typhi, dan Staphylococcus aureus dengan Metode Difusi Agar. Bachelor Thesis. Universitas Padjadjaran, Bandung.

Salminen, G. and A. Wright. 1998. Lactic Acid Bacteria. Dekker Inc. New York.

Seydim, Z.G., T. Kok-Tas and A.K. Greene. 2010. Kefir and Koumiss: Microbiology and Technology. In: Development and Manufacture of Yoghurt and Other Functional Dairy Products. (F. Yildiz, Ed). CRC Pr. London.

SNI. 2009. SNI 2981:2009. Yoghrt. Badan Standarisasi Nasional, Indonesia
Sodini, A. Lucas, M.N. Oliveira, F. Rameuf and G. Corrieu. 2002. Effect of milk base and starter culture on acidification, texture, and probiotic cell counts in fermented milk processing. J. Dairy Sci. 85:2479-2488.

Steel, R.G.D. and J.H. Torrie. 1991. Principle Procedure of Statistics. $2^{\text {nd }}$ Ed. McGrawHill, Inc., New York.

Surono, I.S. 2004. Probiotik Susu Fermentasi dan Kesehatan. Tri Cipta Karya. Jakarta.

Tamime, A.Y. 2006. Fermented Milks. A Blackwell Publishing Company. London.

Wang, J., X. Chen, W. Liu, M. Yang, Airidengcaicike and H. Zhang. 2008. Identification of Lactobacillus from koumiss by conventional and molecular methods. Eur. Food Res. Technol. 227:1555-1561 